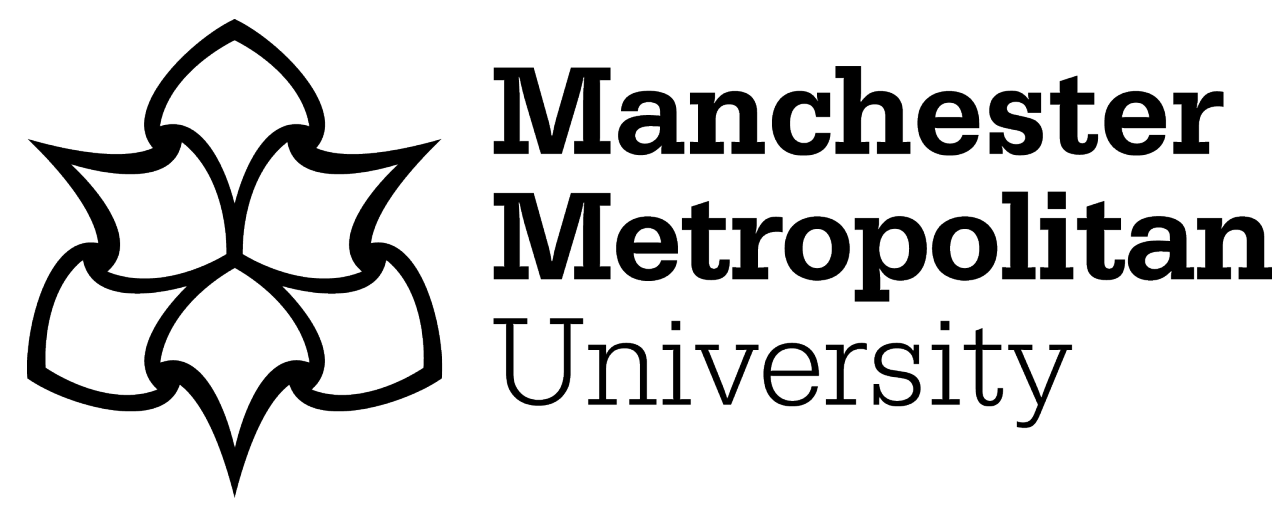

Boardman, R, Haschka, $\mathrm{Y}$, Chrimes, C ORCID logoORCID: https://orcid.org/0000-0002-4710-9885 and Alexander, B (2020) Fashion "see-now-buy-now": implications and process adaptations. Journal of Fashion Marketing and Management, 24 (3). pp. 495-515. ISSN 1361-2026

Downloaded from: https://e-space.mmu.ac.uk/627501/

Version: Accepted Version

Publisher: Emerald

DOI: https://doi.org/10.1108/JFMM-08-2019-0180

Please cite the published version 


\title{
Fashion "see-now-buy-now": implications and process adaptations
}

\author{
Rosy Boardman \\ The University of Manchester, Manchester, UK \\ Yvonne Haschka \\ London College of Fashion, University of the Arts, London, UK \\ Courtney Chrimes \\ The University of Manchester, Manchester, UK, and \\ Bethan Alexander \\ London College of Fashion, University of the Arts, London, UK
}

\begin{abstract}
Purpose - The purpose of this paper is to identify if and how the see-now-buy-now model impacts the traditional buying, merchandising and supply chain processes (BMSCP) of multi-brand fashion retailers (MBFR) and whether they need to be adapted in order to facilitate this development.

Design/methodology/approach - This exploratory study includes three industry case studies, triangulated with external observers. A total of 11 semi-structured interviews were conducted within Germany and the UK. Findings - Findings demonstrate that in order to adopt the see-now-buy-now model there is a need for process-shortening, as well as better process and network alignment between MBFR and brands through agility, supplier-relationship management and vertical integration in order to stay competitive against timebased competition. Whilst most steps of the traditional BMSCP are still applicable under the see-now-buy-now model, they must be re-engineered and shortened, with the steps being rolling rather than linear, with buyers and merchandisers operating in a more hybrid role.

Originality/value - This paper addresses the lack of research on the see-now-buy-now model as well as on the BMSCP of MBFR and the implications that see-now-buy-now could have on those processes. A modified buying, merchandising and supply chain framework adapted to incorporate see-now-buy-now is created which will be useful for academics and practitioners.
\end{abstract}

Keywords See-now-buy-now, Fashion buying, Merchandising, Supply chain management,

Fashion business model

Paper type Research paper

\section{Introduction}

Recently, a democratisation of fashion through an increased inclusivity and accessibility of fashion shows has occurred. The promotion of brands' collections on social media during and directly after fashion shows has facilitated a desire for fashion immediacy amongst consumers (Mountney and Murphy, 2017). Catering to consumers' need for instant gratification, the "see-now-buy-now" model reduces the traditional time-to-market from six months to immediately after the fashion show or next day (Berg et al., 2018). This creates an urgency to "buy now", resulting from consumers' need for stimulation after seeing an item on the catwalk. Therefore, a shift in the fashion calendar from traditionally "out-of-season" to "in-season" appears to be taking place, resulting from the presentation of merchandise for the current season. Thus, see-now-buy-now is a disruptive innovation, challenging the traditional fashion business model of the biannual fashion shows displaying items six months in advance of the season in which items are available to buy and changing the nature of fashion consumption.

Due to the adoption of the see-now-buy-now model by some brands and not others, retailers that sell multiple brands may find this extremely challenging. Multi-Brand Fashion 
Retailers (MBFRs) need to coordinate multiple brands and their different buying, merchandising and supply chain processes (BMSCP) through the adoption of different business models (Hagemuüller and Wolff, 2017). Thus, logistical complexity is created for MBFRs as the alignment of orders, production and delivery schedules with suppliers is needed as a result of the adoption of see-now-buy-now by some brands and rejection by others. Therefore, this study aims to investigate the implications on MBFR's BMSCP resulting from the adoption of the see-now-buy-now model by some brands. In order to achieve this, two research questions are posed:

$R Q 1$. What are the implications, imperatives and barriers of see-now-buy-now on the traditional buying, merchandising and supply chain processes of Multi-Brand Fashion Retailers?

$R Q 2$. What are the steps of the buying, merchandising and supply chain processes of Multi-Brand Fashion Retailers under see-now-buy-now?

By answering these questions, a modified buying, merchandising and supply chain process model, adapted to incorporate see-now-buy-now, will be established.

The paper is structured as follows: firstly, a literature review of see-now-buy-now, fashion buying and merchandising and supply chain management is conducted in order to establish and critically evaluate the current practices and academic research in these areas. This is followed by a discussion of the method carried out in the present study, outlining the research design and rationale. Finally, the findings from the case studies and in-depth interviews are analysed and reported alongside a discussion comparing and contrasting them to extant literature, followed by future recommendations and research limitations.

\section{Literature review}

\subsection{See-now-buy-now}

See-now-buy-now is a business model that makes fashion items instantly available for customers to purchase after the collection is presented for the first time (Coresight Research, 2018). Burberry was the first brand to adopt see-now-buy-now during the Spring/Summer-17 Fashion Show season in September 2016 with other brands following suit such as Mulberry, Ralph Lauren and Topshop Unique. See-now-buy-now is one of the latest developments in the fashion industry which is increasingly becoming more consumer-centric in order to keep up with the changing nature of fashion consumption.

Under see-now-buy-now, collection samples need to be finalised three months before the fashion show for buyers and press to preview the collection in private show rooms or through look-books where non-disclosure agreements are signed (Panchmatia, 2017). Orders are then placed during and after the private show, which serves as the catalyst for production planning and commencement. Therefore, the order process is similar to the traditional business model, where a collection-inspection and order placement is done by buyers after fashion shows, but it is shifted ahead in time. A prerequisite for this is a rapid sourcing model through lead-time reduction, as well as the shortening of production cycles and supplierrelationship management (Brown, 2016; Mountney and Murphy, 2017). Considering the inherent process changes and lack of research on see-now-buy-now, it is necessary to research the impact of see-now-buy-now on MBFR, that are not vertically-integrated, so may find this particularly challenging.

There is a paucity of research on see-now-buy-now. Hines and McGowan (2002) allude to the potential of see-now-buy-now within their research on product life cycles and Macchion et al. (2015) discuss hybrid fashion business model strategies between fast-fashion and luxury businesses which reveals similarities to the see-now-buy-now business model. Yet, both studies focus on business strategies rather than processes and investigate manufacturers not 
MBFRs. Furthermore, neither actually investigates see-now-buy-now in its present form as the concept did not exist when these studies were conducted. Thus, research on see-now-buynow from the viewpoint of a MBFR's buying, merchandising and supply chain process does not exist. This present study will fill this gap.

\subsection{Multi-brand fashion retailers}

Multi-brand fashion retailers are retailers that sell several apparel brands' products within their store (Woodworth, 2018). Multi-brand fashion retailers dominate luxury sales growth online and offline (Woodworth, 2018) and can take the form of department stores; specialty stores where one product segment dominates the retail offer; outlet stores offering secondquality or last-season's products at a discounted price and e-commerce websites which could be outlet stores, department stores or specialist stores (Varley and Rafiq, 2014). These can further be classified according to ownership format: operating as independent (individual store or chain), multiple stores under the same ownership, concessions or wholesale (Varley and Rafiq, 2014). As this study investigates the first purchase of new collections, full-price MBFRs operating as independents or chains through wholesale (branded) buying are investigated as they have direct control over merchandise assortment and the buying and merchandising processes (Sherman, 2017).

\subsection{Fashion buying and merchandising}

Fashion buying is defined as the selection and purchase of merchandise for a specific market to be stocked within retail stores (Goworek, 2007; Shaw and Koumbis, 2014). A fashion buyer's primary role is the selection, negotiation and purchase of merchandise for a retailer working in close collaboration with merchandising and supply chain functions (Shaw and Koumbis, 2014; Varley, 2014; Clark, 2014). Buying functions within department stores are divided into product categories and involve teams made up of multiple people, each required to adhere to rigid processes and timescales. This lack of flexibility in the role and responsibilities of a buyer might pose difficulties in the adaption of see-now-buy-now. The processes for fashion buying for MBFR are relatively unexplored as literature focuses on organisational buying for own-labels (Brandes, 1994; Johnston and Lewin, 1996; Jackson and Shaw, 2001; Goworek, 2010; Shaw and Koumbis, 2014; Varley and Rafiq, 2014; Varley, 2014). To establish a buying process for MBFR, knowledge is drawn from the works of Johnston and Lewin (1996), Johansson (2001), Goworek (2007), Shaw and Koumbis (2014), Varley and Rafiq (2014) and Clark (2014), whilst the influence of MBFR characteristics on the buying process is determined based on the works of Webster and Wind (1972), Johnston and Lewin (1996), Jackson and Shaw (2001), Johansson (2001), Perry and Kyriakaki (2014) and Varley and Rafiq (2014).

Merchandising is the assurance of the right product quantity in the right place at the right time whilst meeting the company's financial goals (Levy and Weitz, 2004). The merchandiser's role incorporates stock management, budgeting, forecasting, as well as delivery and allocation planning to ensure an efficient stock flow (Jackson and Shaw, 2001; Clark, 2014). Prior studies understand merchandising as product management (Rosenau and Wilson, 2014; Varley, 2014) and focus on the role of merchandisers in relation to buyers (Jackson and Shaw, 2001; Clark, 2014), or merchandise planning for own-label products (Kunz and Rupe, 1999; Jackson and Shaw, 2001; Bruce and Daly, 2006; Goworek, 2007, 2010; Perry and Kyriakaki, 2014; Shaw and Koumbis, 2014; Clark, 2014; Varley, 2014), both of which are not applicable to MBFR that have to select finished branded products amongst several alternatives.

To frame activities that buyers and merchandisers undertake when curating fashion ranges, the processes identified for this study are based on Johnston and Lewin (1996), 
JFMM

24,3

498
Goworek (2007), Shaw and Koumbis (2014), Varley and Rafiq (2014) and Clark (2014)'s research on fashion buying as well as Johansson (2001)'s research on organisational buying (Figure 1). The timing is based on Goworek's (2007) buying cycle.

"Sales, performance review and forecasting" fall under merchandising tasks (Varley, 2014; Varley and Rafiq, 2014; Clark, 2014), whilst "budget planning and negotiation" and "budget confirmation" is conducted collaboratively between buyers and merchandisers (Clark, 2014; Shaw and Koumbis, 2014). "Assortment planning" and "initial seasonal buying plan" appear to be equal to the creation of a "merchandise plan".

\subsection{Supply chain management}

The supply chain is the collection of actions and sequentially integrated business partners required to coordinate and manage all activities necessary in bringing products to the market (Jackson and Shaw, 2001) making supply meet demand (Fisher and Raman, 1996). Literature largely focuses on supply chain from a manufacturer's point-of-view (Jacobs, 2006; Mehrjoo and Pasek, 2014) or vertically-integrated companies comprising manufacturing and retailing of own-label products (Mattila et al., 2002; Jacobs, 2006; Swoboda, et al., 2010; Rosenau and Wilson, 2014; Mehrjoo and Pasek, 2014; Fernie and Sparks, 2014; Fernie and Grant, 2015), fast-fashion (Hines and McGowan, 2002; Mehrjoo and Pasek, 2014; Fernie and Grant, 2015) or the replenishment supply chain (Mattila et al., 2002; Jacobs, 2006). No literature on the supply chain of first purchases between MBFR and brands from a process point-of-view in the field of fashion exists. To determine the steps within the supply chain process between MBFR and brands as well as supply chain influences and characteristics, information is gathered from Christopher et al. (2004), Jacobs (2006), Goworek (2007), Reichhart and Holweg (2007), MacCarthy and Jayarathne (2013), Varley and Rafiq (2014), Clark (2014), Fernie and Sparks (2014), Fernie and Grant (2015) and Macchion et al. (2015).

In relation to the buying and merchandising process (Figure 1), the first part of the process comprises the pre-purchase demand chain whilst the post-purchase steps are supply chain functions (Jacobs, 2006). Based on research on the fashion retail supply chain (Clark, 2014; Varley and Rafiq, 2014; Fernie and Sparks, 2014; Fernie and Grant, 2015) steps within the fashion supply chain for MBFR were identified and timed according to Goworek's (2007) buying cycle (Figure 2).
Figure 1.

Buying and Merchandising Process (Developed from Johnston and Lewin, 1996; Johansson, 2001; Goworek, 2007; Kumar and Banga, 2007; Iannone et al., 2013; Shaw and Koumbis, 2014; Varley and Rafiq, 2014; Clark, 2014)

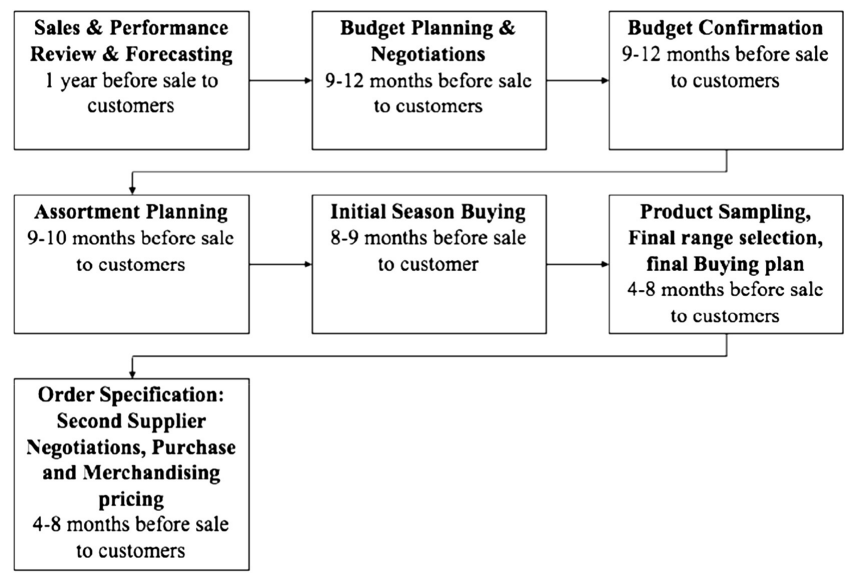




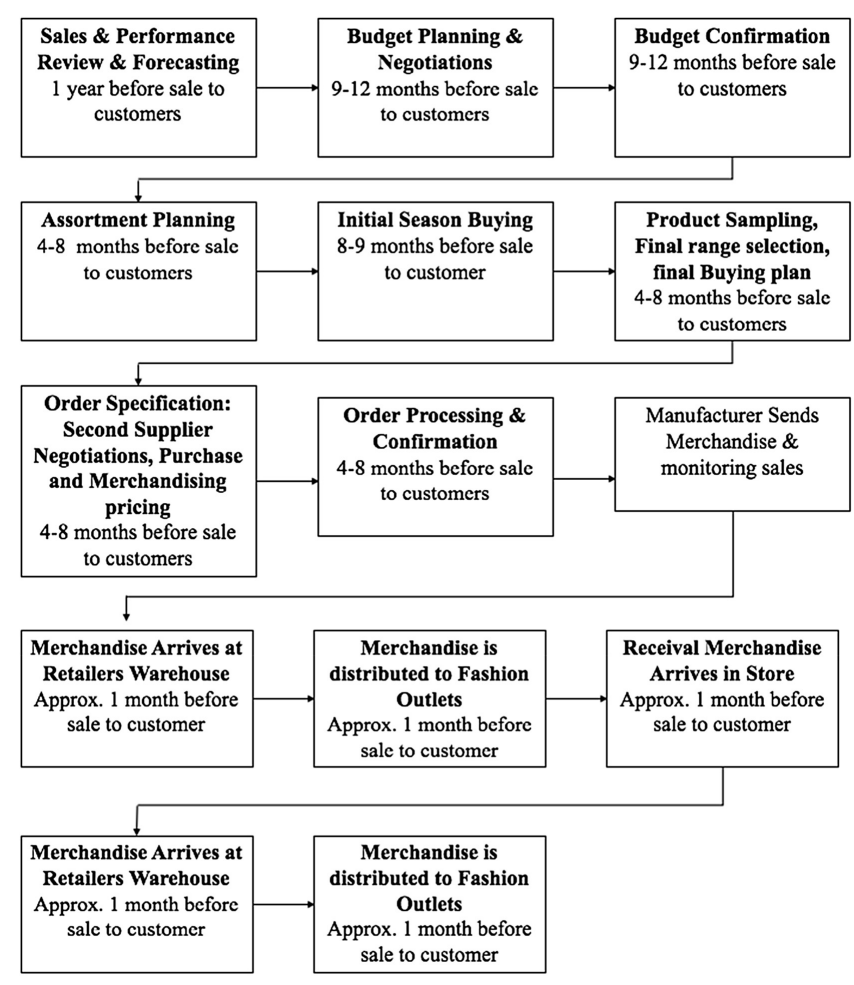

See-now-buynow

499

Figure 2.

Buying,

Merchandising and

Supply Chain Process (Developed from:

Johnston and Lewin,

1996; Johansson, 2001;

Goworek, 2007; Kumar and Banga, 2007;

Iannone et al., 2013; Grose, 2012; Shaw and Koumbis, 2014, Varley and Rafiq, 2014; Clark, 2014; Fernie and Sparks, 2014; Fernie and Grant, 2015)

In sum, no research exists on see-now-buy-now's implications on the traditional BMSCP of MBFR, a gap that the present study will fill.

\section{Methods}

This exploratory study uses industry case studies and qualitative in-depth interviews to analyse see-now-buy-now within a real-life context. By conducting case studies, a deeper understanding of the see-now-buy-now context, potential processual changes and implications on the traditional BMSCP by multiple industry data sources is delivered (Eisenhardt and Graebner, 2007; Schwandt, 2001). A case study method was adopted as it allowed us to gain insights into BMSCP from participants within the systems themselves in order to provide explanations and expert opinions into how see-now-buy-now would impact those processes (Swanborn, 2010), thus directly addressing our research questions. Firstly, the traditional BMSCP were identified through secondary research and confirmed through case studies before a modified process framework was created through the analysis of the case studies (Yin, 2014). As only the BMSCPs of the organisations were investigated, embedded case studies were used (Yin, 2014).

The cases were chosen through theoretical replication, defined as the case choice based on "different theoretical conditions" of information-rich cases for in-depth information gathering, as the companies are all MBFR but different in their MBFR format (Yin, 2014). In adherence with Yin (2014)'s recommended number of cases for theoretical replication and previous studies examining similar topics (Brandes, 1994; Bruce and Daly, 2006), this case 
JFMM 24,3

500 study treated three cases. A MBFR case selection framework was established based on Sheth's (1981) model of industrial merchandise buying behaviour (see Table 1).

The case studies consisted of retailers stocking multiple brands including see-now-buynow and non-see-now-buy-now brands that are positioned within the luxury or premium segment, all operating under the wholesale format and being at least partially non-verticallyintegrated. These selection criteria ensured an engagement with the problem of the coordination of different brand schedules for BMSCP of MBFR.

Qualitative in-depth interviews were conducted to deliver a deeper understanding of the see-now-buy-now context and processual changes (Eisenhardt and Graebner, 2007). Participants were selected by non-probability homogenous and heterogeneous purposive sampling, as well as snowball and self-selection volunteer sampling (Saunders et al., 2012). Interviewee selection criteria included participants' backgrounds, positions and responsibilities. Each were required to currently work within the field of fashion to obtain up-to-date industry knowledge (see Table 2).

A total of 11 in-depth interviews were conducted (four as part of the case studies and seven additional ones with external observers). Data saturation point was reached. Interviews were conducted face-to-face, lasting approximately 30-60 min, adhering to the recommended guideline for in-depth interviews (Jamshed, 2014). An interview guide kept the interview focused on key themes whist allowing participants' individual perspectives and experiences to emerge (Patton, 2015). The interview guide (Table 3) was adapted to suit each individual and their role, thus the number of topics and questions varied depending on participants' backgrounds and themes under investigation (Saunders et al., 2012).

A pilot case including two interviews were conducted with department store managers in order to ensure question clarity and that the appropriate themes could be explored. Pilot studies were not included in the data.

Case data were analysed by means of cross-case synthesis, described as the determination of replications or contrasts between cases through argumentative interpretations of text data categorised in word-tables (Schwandt, 2001; Yin, 2014; Patton, 2015). Each case was treated as a separate study to compare findings (Yin, 2014). Individual case data were displayed separately within one analytical framework (Patton, 2015) according to five uniform categories (Johansson, 2001; Yin, 2014) within a case-ordered descriptive meta-matrix. Due to the MBFR case selection based on theoretical replication, similarities and contrasts were predicted and incorporated in the case design.

The case study findings were reported in a linear-analytical approach to connect the implications of see-now-buy-now on the traditional BMSCP of MBFR to existing research to

\begin{tabular}{|c|c|c|c|}
\hline Criteria & $\begin{array}{l}\text { Case 1: German } \\
\text { independent department } \\
\text { store }\end{array}$ & $\begin{array}{l}\text { Case } 2 \text { : UK chain } \\
\text { department store }\end{array}$ & $\begin{array}{l}\text { Case 3: German } \\
\text { independent boutique }\end{array}$ \\
\hline Multiple Brand & Yes & Yes & Yes \\
\hline Type of Products & Fashion and Accessories & $\begin{array}{l}\text { Fashion and } \\
\text { Accessories }\end{array}$ & $\begin{array}{l}\text { Fashion and } \\
\text { Accessories }\end{array}$ \\
\hline Product Positioning & Luxury/ Premium & Luxury/ Premium & Luxury/ Premium \\
\hline $\begin{array}{l}\text { Mix of SEE-NOWs-BUY-NOW } \\
\text { and Non-SEE-NOW-BUY-NOW } \\
\text { brands }\end{array}$ & Independent & Chain & Independent \\
\hline Vertical Integration & No & Yes & No \\
\hline $\begin{array}{l}\text { Wholesale Model (at least } \\
\text { partially) }\end{array}$ & $\begin{array}{l}\text { Mainly wholesale and a } \\
\text { few concessions }\end{array}$ & $\begin{array}{l}\text { Partially wholesale } \\
\text { and concessions }\end{array}$ & $\begin{array}{l}\text { Only wholesale, no } \\
\text { concessions }\end{array}$ \\
\hline
\end{tabular}

Table 1.

Case selection criteria (based on Seth, 1981) 


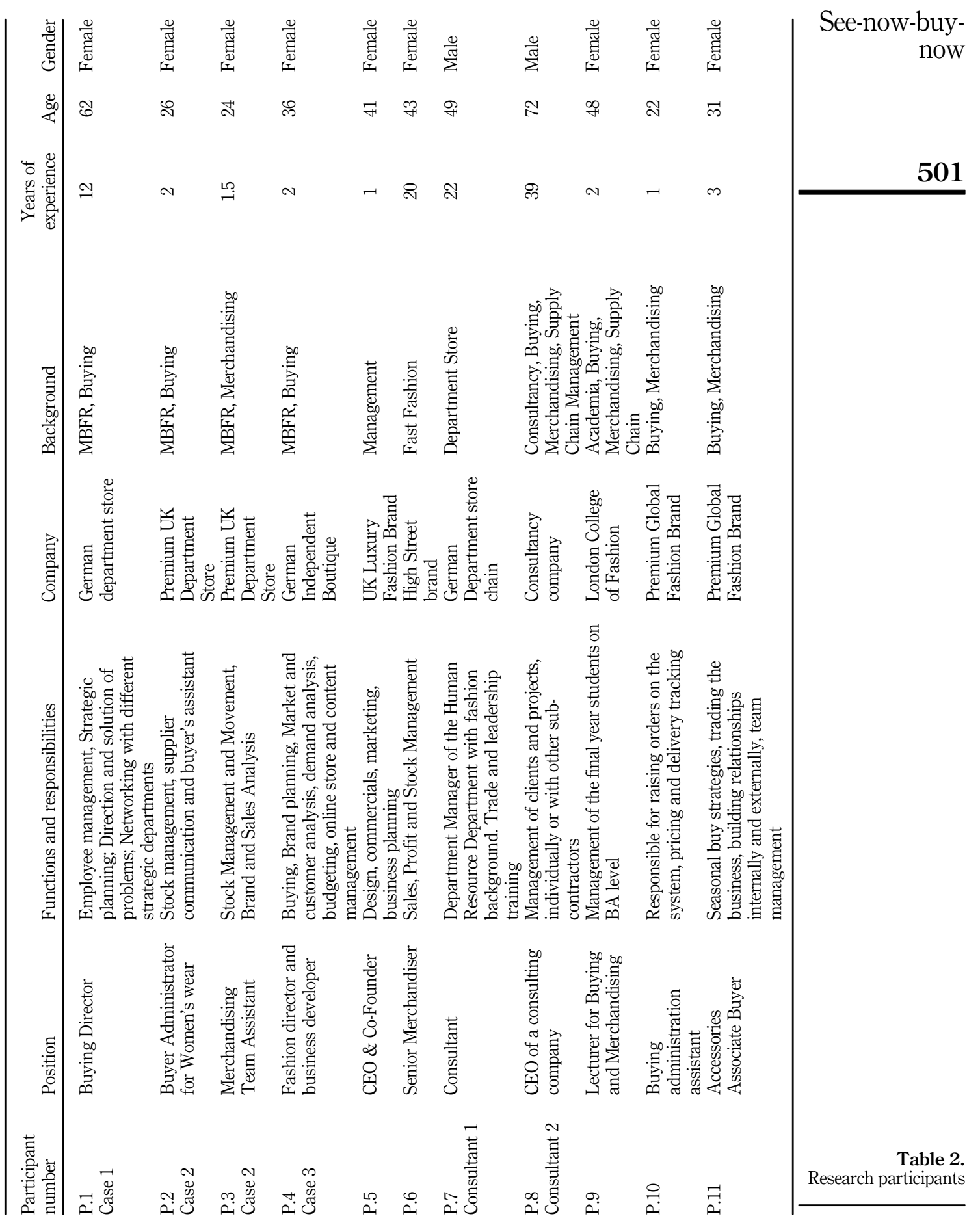


JFMM

24,3

502

Interview Technique (Kvale, 2007)

Participant Number (Kvale, 2007)

Participant Background (Kvale, 2007)

Research Field (Kvale, 2007)

Purpose (Kvale. 2007; Saunders et al., 2012)

$\underline{\text { Interview number }}$

Date (Kvale, 2007; Milnes et al., 2014)

Location (Kvale, 2007; Milnes et al., 2014)

Interview Type (Kvale, 2007)
Yes / No

Yes / No

Date

Semi-structured (Saunders, Lewis, Tornhill, 2008)

Exploratory - seeking new angles on the topic (Kvale, 2007)

Confrontational - confirm traditional buying, merchandising and supply chain process identified (Kvale, 2007)

Phenomenological - capturing person's live experience of seenow-buy phenomenon (Patton, 2015)

Funnel-shaped interview - from general questions to specific (Kvale, 2007)

General

Obtain knowledge about see-now-buy-now phenomenon and its implications on the traditional buying, merchandising and supply chain process of MBFR

Specific: tbd

develop the case study design (Yin, 2014; Patton, 2015). This research method was deemed appropriate in understanding if and how see-now-buy-now has affected the fashion industry

Table 3.

Interview guide, author's own, adapted from Saunders $e t$ al. (2012), Milnes et al. (2014), (Müller et al., 2018), Yin (2014)

\begin{tabular}{|c|c|c|}
\hline Interview Part 1 - Structured & Question number & Question \\
\hline Demographic question (Patton, 2015) & 1 & How old are you? (Patton, 2015) \\
\hline $\begin{array}{l}\text { Experience and behaviour question (Patton, } \\
\text { 2015) } \\
\text { Background question (Patton, 2015) }\end{array}$ & 2 & $\begin{array}{l}\text { What is your position and what are your } \\
\text { functions in the organization? (Müller } \text { et al., } \\
\text { 2018) }\end{array}$ \\
\hline Background question (Patton, 2015) & 3 & $\begin{array}{l}\text { How long have you been active in this role? } \\
\text { (Müller et al., 2018) }\end{array}$ \\
\hline $\begin{array}{l}\text { Experience and behaviour question (Patton, } \\
\text { 2015) } \\
\text { Background question (Patton, 2015) }\end{array}$ & 4 & $\begin{array}{l}\text { What specific tasks and areas of } \\
\text { responsibility does your position } \\
\text { encompass? (Müller } \text { et al., 2018) }\end{array}$ \\
\hline $\begin{array}{l}\text { Research Objectives (Saunders et al., 2012; } \\
\text { Oppenheim, 1992) }\end{array}$ & $\begin{array}{l}\text { Research Question } \\
\text { (Saunders et al. 2012; } \\
\text { Oppenheim, 1992) }\end{array}$ & $\begin{array}{l}\text { Interview Questions Saunders et al. (2012); } \\
\text { (Oppenheim, 1992) }\end{array}$ \\
\hline Interview Part 2 - Unstructured & Theme Number & Theme (Milnes et al. (2014) \\
\hline $\begin{array}{l}\text { Questions asked of all participants that draw } \\
\text { on literature and go beyond the scope of this } \\
\text { study (Yin, 2014) }\end{array}$ & 1 & SEE-NOW-BUY-NOW \\
\hline $\begin{array}{l}\text { Questions asked of individual case and } \\
\text { specific individuals as to determine patterns } \\
\text { across cases (Yin, 2014) }\end{array}$ & 2 & MBFR \\
\hline $\begin{array}{l}\text { Questions asked of specific individuals as to } \\
\text { determine patterns across cases (Yin, 2014) }\end{array}$ & 3 & Buying \\
\hline $\begin{array}{l}\text { Questions asked of specific individuals as to } \\
\text { determine patterns across cases (Yin, 2014) }\end{array}$ & 4 & Merchandising \\
\hline $\begin{array}{l}\text { Questions asked of specific individuals as to } \\
\text { determine patterns across cases (Yin, 2014) }\end{array}$ & 5 & Supply Chain Management \\
\hline
\end{tabular}

prior to data collection (Kvale, 2007; Milnes et al., 2014)

Oppenheim, 1992)

Theme Number

Theme (Milnes et al. (2014)

SEE-NOW-BUY-NOW

Questions asked of individual case and

specific individuals as to determine pattern

Questions asked of specific individuals as to

determine patterns across cases (Yin, 2014)

Questions asked of specific individuals as to

Questions atterns across cases (Yin, 2014)

determine patterns across cases (Yin, 2014)
How old are you? (Patton, 2015)

functions in the organization? (Müller et al., 2018)

(Müller et al., 2018) encompass? (Müller et al., 2018)

Interview Questions Saunders et al. (2012);

(n)
. 
through the investigation of multiple viewpoints (Saunders et al., 2012) and generates data to identify themes and patterns in order to abductively generate a modified BMSCP for MBFR with see-now-buy-now brands (Gabriel and Griffiths, 2004).

Interviews were analysed by means of first and second cycle coding, starting with data reduction through first cycle coding where data was assigned labels through essence description (Milnes et al., 2014). During the coding process, large amounts of data were analysed through data disaggregation, breaking it down into manageable segments, conducting on-going comparisons, categorisations and classifications (Schwandt, 2001). Meaningful statements were analysed through the creation of meaning units (codes) via meaning condensation of emerged information. Within second cycle coding, sub-codes within the first cycle codes were established to determine patterns (Milnes et al., 2014). To display and classify the categories, codes and sub-codes were attached as either descriptive or attribute codes (Milnes et al., 2014), thus a coding framework was established based on the literature review and emergent data (Milnes et al., 2014; Patton, 2015). Following this, the data was displayed according to the research questions and then in form of conceptually clustered checklist matrices to analyse the collected data according to variables and themes evidenced (Yin, 2014; Milnes et al., 2014). This aided the analytical process through hierarchical data depiction as well as identification of patterns, themes, categories, relationships and emergent issues connected to see-now-buy-now (Yin, 2014; Patton, 2015). The researchers coded parts of the data sets individually first, before discussing emerging patterns in order to ensure reliability.

\section{Results and discussion}

RQ1: What are the implications, imperatives and barriers of see-now-buy-now on the traditional BMSCP of MBFR?

\subsection{Case study findings: see-now-buy-now obstacles}

Table 4 depicts the see-now-buy-now obstacles identified by the case study and triangulation findings:

It is apparent from Table 4 that three predominant obstacles of the see-now-buy-now model emerged from the discourse including: Power Relationship, Products and Process. These three themes will now be discussed in more detail.

See-now-buy-now obstacles: power relationship

Participants revealed that the see-now-buy-now model is expected to empower brands as, "brands call the shots because they produce the line and they know the production minimums they are going to offer" (P2). This infers that MBFR are expected to lose some bargaining power with the see-now-buy-now model as the brands themselves will be the ones that decide the quantity that they will produce because it needs to be completed in advance of the fashion show in order to be ready to be sold immediately, thereby leaving MBFRs having to just accept this. Hence, this suggest that if MBFR stock brands that are operating a see-now-buynow strategy, it could negatively influence the power that they have over the brands that they purchase from.

Furthermore, data revealed that MBFRs' feel that see-now-buy-now strengthens the relationship that the brand has directly with the customer, one which they did not have in the traditional buying cycle as the MBFR was the one that sold the brand's items directly to the customer. See-now-buy-now means that the brand decides what is included in the product range that they display at the fashion show, and the MBFR buyer decides whether they want to stock it or not just beforehand without knowing consumer demand, thus, mostly having to buy everything from the range rather than carefully analysing which ones to choose based on 
JFMM 24,3

\section{4}

\begin{tabular}{lll} 
Variables & Cases & Triangulation \\
\hline
\end{tabular}

Power (1) Empowerment of Brands- MBFR loose Relationship power (P2)

Products

(1) Difficulty in purchasing products virtually even for brand where close relationships are already established, as fashion items need to be touched, observed and sampled due to various fits, material and qualities (P4)

(2) Exchange of products due to quality issue is not possible anymore (P4)

(3) Handcraft which is prevalent in the premium and luxury segment appears to pose a major challenge as shorter production times impact quality (P2)

(4) Difficulties in selling late-delivered products as this would decrease the turnover through low sell-through which effectively poses challenges on the achievement of turnover plans (P1)

Process (1) Delivery - concerns about punctual delivery of items (P2)

(2) Warehousing - circumventing the warehousing would affect the analysis and reporting of stock $(\mathrm{P} 2)$
(1) Shorter lead-times would make MBFR more dependent on brands as their reaction time to trends is shorter and without a counter-action possibility (P7;8;9) - MBFR lose power

(2) Manufacturers might not be able to adhere, as they have contracts with producers themselves (P7)

(1) Consumer-driven supply chain is dependent on sale (reductions) and current customer trends implying the danger of over- or under-stock due to up-front planning $(\mathrm{P} 5 ; 7 ; 8)$ resulting in lost sales or too high inventory (P9)

(2) SEE-NOW-BUY-NOW model only works with a high sell-through, otherwise price reductions would be needed to increase sell-through as new goods are delivered, even though the previous collection has not been sold (P5;7;8)

(1) Process wastage might occur due to changes in the market or customer demand which differs from the plan (P9)

(2) Business systems might not be as advanced to allow for a customercentric information sharing between MBFR and manufacturers which would hinder the alignment of processes (P9) leading to confusion between partners (P6)

(3) Production time is difficult to shorten (P5;6;9)

(4) Air-freight would offer quick delivery but is expensive $(\mathrm{P} 6 ; 9)$ - increasing prices for consumers, resulting in consumer dissatisfaction due to price sensitivity (P10) not bought it, my customers cannot buy it from me, the retailers are cut out. . . the brand kind of circumvents the retailers" (P1). Indeed, the sentiment that see-now-buy-now would alter fashion shows' purpose and become sales events for the brands to sell to customers, as opposed to their traditional purpose of enabling buyers to see the brand's collections and then order what they want to stock 6 months in advance, was acknowledged as being prevalent amongst external observers (P5;7;8).

This supports previous research on the power relationship between brands and retailers (Berman and Evans, 2013; Sherman, 2017). In particular, small independent MBFR within the 
luxury segment seem to have the least bargaining power over manufacturers due to their limited order quantity, whilst bigger chain MBFR within the mid-market segment appear to have the most (Berman and Evans, 2013; Lockwood and Edelson, 2016). Thus, it appears that see-now-buy-now favours bigger chain MBFR through their ability to withhold brands if they do not want to stock them due to the amount of alternative brands that they could stock instead. Furthermore, it was identified that with see-now-buy-now, MBFR would want more flexible contracts. However, participants revealed that manufacturers may not be able to adhere to these types of contracts "[...] because they have contracts with producers themselves" (P7). Therefore, changing systems or processes could affect the whole company, leading to confusion between partners (P6) which could restrict network-integration. Previous studies that have shown the tendency of MBFR to avoid stocking brands that adopt the see-now-buy-now model due to these complications (ATKearney, 2018).

See-now-buy-now obstacles: products

Participants also regarded products to be an obstacle for see-now-buy-now. Interviews revealed that, although viewing and purchasing upcoming collections through virtual lookbooks and order systems saved time, it appeared to be difficult as, "even with brands that we have worked with for a long time, you always need to see and touch the products in the showroom" (P4). This poses risks for MBFR as they are not able to actually see and feel the product before they commit to ordering it from brands, and if it differs from their expectations and is not as aligned with their target customer's preferences as originally thought when having seen it virtually, then this could result in a loss of sales. Indeed, as P4 surmised: "purchasing based on images or in platforms does not work because then you have the items which you imagined looking completely different, or the fit or the materials are not what you expected, etc. And then you cannot exchange it anymore because the brands just want to get rid of their products". This concurs with previous literature that information gained from a physical inspection of an item is particularly important when the product has certain attributes that cannot be evaluated effectively otherwise (Grohmann et al., 2007) and that by just seeing items on a digital platform means not being able to see or touch an item, which increases product uncertainty (Peck and Childers, 2003). The lack of flexibility that brands provide buyers by not allowing them to return or exchange items once they have arrived could be very costly for MBFR in terms of lost sales, as well as costly to the environment if many products end up in landfill as a result.

Furthermore, the interviews revealed that, despite some of the buyers of MBFR having built up close relationships with the brands (suppliers), the importance of retaining as much control over the product range as possible prevented the brands from allowing buyers to view collections in person, leaving buyers to feel like there was a lack of trust developing, harnessing feelings of frustration: "At some point, I need to see what is coming, or at least know that is coming!" (P1). This suggests that see-now-buy-now could have a detrimental effect on the buyer-supplier relationship and a step backwards from the more collaborative buyer-supplier relationship that is being promoted recently, as collaborative relationships foster shared values and norms as well as information exchange (Hoegl and Wagner, 2005). The importance of the buyer-supplier relationship is well-documented in the literature (Kim and Choi, 2015; Narayanan et al., 2015; Blessley et al., 2018) and a breakdown in this entity could be very costly to retailers (Boardman et al., 2020). Indeed, Blessley et al. (2018) found that a breach in relational obligations between the buyer and supplier has negative consequences and can ultimately lead to the complete breakdown and termination of the buyer-supplier relationship.

A number of participants stated that under see-now-buy-now no correction possibility is given $(\mathrm{P} 4 ; 7 ; 8 ; 9)$ as items are promoted by brands to be available shortly after the fashion show, so the goods need to be ready to sell at the promoted date. Indeed, for buyers "effectively the fashion show is your look book and you cannot correct anything" (P7). As P9 
JFMM 24,3

506 states: with see-now-buy-now "you do not have the opportunity to buy a bit and repeat, you have to just buy it, and buyers will always overbuy". This highlights the increased risk of adopting see-now-buy-now for MBFRs as they are unable to change their order quantities and have to hope that the items that they had forecasted to be best sellers are indeed that popular and fulfil their order potential, and that they have bought enough of the actual best sellers so that they can maximise profits. Hence, it is hard to forecast what to over-buy and under-buy in terms of stock levels as fashion is so consumer-driven, increasing the risk of over- or under-buying stock (P5;7;8) resulting in lost sales or too high inventory (P9). This suggests that the see-now-buy-now model will only work with a high sell-through rate as buyers will generally choose to over-buy items in large quantities. This goes against the way that the fashion industry is moving, with super-fast fashion pureplay retailers now adopting strategies of under-buying in certain riskier items in order to test consumers' reactions, and then reordering in larger quantities only when they know it is a best seller, thereby minimising the risks to the business and maximising profits (Boardman et al., 2020). Thus, it appears that see-now-buy-now would work best for high sell-through items and items that have short lead times in terms of production so that they can be re-bought quickly to capitalise on demand. As a result, participants further disclosed that the see-now-buy-now model requires a trade-off between quality and speed-in-production, which could influence brand perception, making luxury item production-shortening unfeasible (P2;5;6;9).

See-now-buy-now obstacles: process

Participants identified that the implications of see-now-buy-now on the traditional BMSCP of MBFR were also concerned with process and network-integration by means of lead-time reduction and supplier-relationship management. Participants revealed that the traditional BMSCP is not feasible for the see-now-buy-now model (P1) as MBFRs' BMSCP take longer than see-now-buy-now allows for (P4). Thus, "the whole system will have to be restructured" (P1) towards a vertical integration including shorter ways of information-flow and upfront planning $(\mathrm{P} 1 ; 4 ; 5 ; 6 ; 9)$. Consequently, the data suggests that see-now-buy-now may only work for vertically-integrated companies that have close relationships with suppliers, a finding also corroborated by (Panchmatia, 2017). Indeed, participants revealed that business systems are not advanced enough to allow for customer-centric informationsharing between MBFR and manufacturers which would hinder the alignment of processes (P9), making see-now-buy-now difficult to implement. These findings corroborate the problems outlined in prior research that have determined that MBFRs are less flexible in assortment choice and operations (Cooper, 2017; Hargrave, 2015; Varley and Rafiq, 2014).

Furthermore, data found that the cost of the see-now-buy-now process makes it inhibitive for smaller/emerging brands, as discussed by P4, the independent retailer: "It is very costly. For up and coming brands it is more expensive, so you've got to have the money to be able to do it, the investment behind it to do it". This means that it is only really feasible for smaller retailers for "small orders" (P4) as made clear by P7: "logistically, I cannot imagine at all how this would work realistically. You can only do that for selected things. For us this is no-go at the moment. . . over $90 \%$ of the items would still have the classic [model], so you still have six months". This shows that the process of see-now-buy-now would be a significant barrier to any MBFRs that were smaller or independent, and those that were not vertically integrated.

In summary, it seems that these three obstacles would need to be overcome if see-now-buynow was to be implemented.

Case study and triangulation findings: imperatives for see-now-buy-now

Table 5 demonstrates the imperatives for see-now-buy-now as identified by case studies and the triangulation of findings.

Despite the obstacles of see-now-buy-now for MBFRs, the interviews acknowledged that the model would be attractive to consumers: "it is good for customers that want things quickly, so it encapsulates what customers want right now" (P2). Thus, it is worthwhile trying 


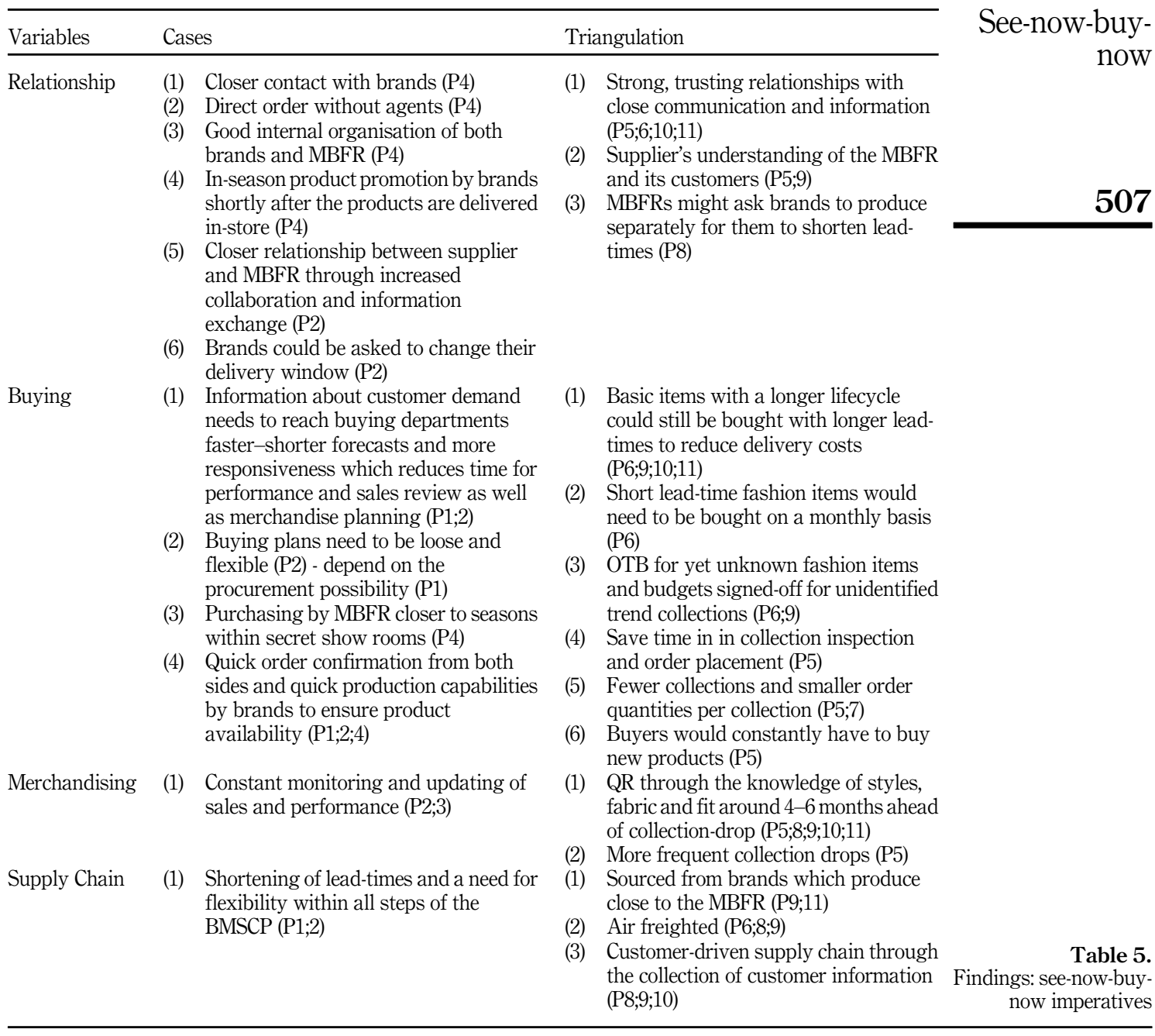

to overcome the barriers in some cases. Participants disclosed that to solve the barriers posed by see-now-buy-now on the traditional BMSCP of MBFR a shortening of lead-times and flexibility within all steps of the BMSCP is necessary (P1;2). This imperative has also been briefly been touched upon by Hines and McGowan (2002). Participants suggested that a customer-driven supply chain through the collection of customer information (P8;9;10), Quick Response (QR) and the supplier's understanding of the MBFR and its customers (P5;9) appears necessary to forecast and plan delivery, stock, floor space, budget and merchandise (P5;8;9;10;11) which would reduce time for performance and sales review as well as merchandise planning $(\mathrm{P} 1 ; 2)$. Hence, the findings infer that the application of $\mathrm{QR}$ and reaction to both internal and external stimuli renders that MBFRs' BMSCPs need to be more agile. These imperatives substantiate prior findings that have also posited that under see-now-buynow there is a necessity to be agile, with a rapid sourcing model through lead-time reduction, shortening of production cycles and supplier relationship management (Mountney and 
JFMM

24,3

\section{8}

Murphy, 2017; Milnes, 2017b; Brown, 2016). Additionally, participants revealed that the constant monitoring and updating of sales and performance is essential (P2;3) to foster quick decision-making and keep buying plans flexible (P2) as they also depend on the stock availability by manufacturers to fulfil customer demand (P1). Thus, closer contact with the brands, direct ordering without agents, trust, information-sharing and a good internal organisation of both brands and MBFR is necessary in order to react flexibly (P4;5;6;10;11).

Some participants also suggested that basic items with longer lifecycles could still be bought with longer lead-times to reduce delivery costs (P6;9;10;11), whilst short lead-time fashion items would need to be bought on a monthly basis (P6) and either sourced from brands which produce close to the MBFR (P9;11) or air-freighted (P6;8;9). Consequently, an Open-To-Buy (OTB) budget for unknown fashion items would need to be kept and budgets signed-off for unidentified trend collections (P6;9). Hence, this infers that the role of OTB is even more important under see-now-buy-now. A pre-requisite for alignment of customer needs and product offer is the purchasing by MBFR closer to seasons and "only when the things are delivered or shortly after delivery are the products promoted" (P4). Therefore, the BMSCP would happen secretly before product promotion and made available directly after fashion shows (P1;4). Hence, product exposure to buyers and commercial availability will merge closer together.

Participants also suggested that shorter processes through centralisation, similar to vertically-integrated retailers (P7;8), implies the elimination of certain process steps (P10), particularly in collection-inspection and order placement, so brands could plan and start production quicker, shortening lead-times (P5). Indeed, participants disclosed that, as a result, there will be fewer collections and smaller order quantities per collection but more frequent collection drops, which might increase sell-through as, "the buyer constantly needs new things and the designer constantly needs to create" (P5). Yet, participants also stated that a fast sell-through due to short product lifecycles must be supported through quick order confirmation from both sides and quick production capabilities by brands to ensure product availability (P1;2;4) which effectively fosters turnover. Therefore, it appears that order seasons would change to a fluid model as opposed to seasonal order periods. Consequently, participants surmised that see-now-buy-now would work better for the luxury segment (P7) due to higher channel control, exclusivity and lower production quantity (P8;9) than the midmarket segment. This finding offered a potential reason as to why see-now-buy-now has currently only been implemented by luxury and affordable luxury levels with premium price points (Coresight Research, 2018).

Finally, participants acknowledged that depending on the power relationship, brands could be asked to change their delivery window (P2) or produce separately for them (P9), which would give the MBFR more time to control and allocate the merchandise and shorten lead-times, implying a change in the way that they collaborate but not a change of the power relationship (P8).

Thus, in sum, it is apparent from this discourse that a pre-requisite to integrate the seenow-buy-now model in MBFRs' BMSCP is an agile supply chain, process-shortening and close relationships between MBFR and suppliers to optimally cater to customer demand at its peak.

\subsection{RQ2: what are the steps of the buying, merchandising and supply chain processes of multi-brand fashion retailers under see-now-buy-now?}

Data revealed that the steps of the traditional BMSCP are still applicable but need to be reengineered and shortened in order to incorporate the see-now-buy-now model (Table 6).

Participants identified that all steps before collection viewing could be accelerated, however, production cannot be shortened due to the refined nature of premium products 
Applicable

(1) Sales and Performance Review and Forecasting

(2) Budget Planning and Negotiations

(3) Budget Confirmation

(4) Assortment Planning

(5) Order Specification, Supplier Negotiation, purchase and Merchandise Pricing

(6) Order Processing and Confirmation (only named by MBFR cases)

(7) Manufacturer Sends Merchandise and Monitoring of Deliveries

(8) Merchandise Arrives in Store

(9) Merchandise Checking and Preparation for Final Customer to purchase

(10) Merchandise Ready for Customers to purchase
Differences between case and triangulation findings

See-now-buynow

(1) Merchandise Arrives at Retailers Warehouse

(2) Product Sampling, Final range Selection, Final Seasonal Buying Plan

(2) Merchandise is

Distributed to Fashion Outlets

(P1;2;4). This suggests that sales, performance, market, customer and competitor analysis need to be conducted on a continuous basis during the season, facilitating a quick review to establish and confirm the buying budget and merchandise plan. Therefore, it appears that no initial seasonal buying plan needs to be established, as the quick reaction to trends based on the preceding analysis and brand offer makes it redundant. As such, the collection-viewing serves as the buying appointment where supplier negotiations are done and the collection is ordered directly from the manufacturer. This extrapolates that no separate product sampling, final range selection and final seasonal buying plans are established as those steps are done within the buying appointment to react flexibly to current market preferences. Therefore, this suggests that MBFR's internal steps should be compressed. This finding offers a new perspective compared to the research of Shaw and Koumbis (2014), Johansson (2001), Johnston and Lewin (1996), Goworek (2007), Varley and Rafiq (2014), Clark (2014), Iannone et al., (2013), Kumar and Banga (2007) and Kök et al., (2006) on buying and merchandising processes, and Fernie and Sparks (2014), Fernie and Grant (2015), Grose (2012) on supply chain processes, which describe the BMSCP as consecutive and lengthy.

Participants also revealed that whilst the products are under production, MBFRs could work on the critical path for supplier deliveries to plan for floor space, allocation, inventory and set price-points. Products are delivered via air-freight directly to the MBFRs' stores in small batch deliveries. The delivery of merchandise to warehouses and subsequent distribution would take too much time, therefore, these steps could be circumvented. This is enabled through the constant and close exchange of information about sales, customer preferences, trends and product development between brands (suppliers) and MBFR. The necessity of a close buyer-supplier relationship under see-now-buy-now is consistent with the traditional BMSCP and its increasing importance in the fashion industry in general due to highly unpredictable consumer demand (Boardman et al., 2020). Once arrived in stores, the goods are controlled and prepared for customers within $24 \mathrm{~h}$, which corresponds with the current retail model. 
JFMM

24,3

510
Figure 3.

Framework

Development of the

BMSCP Adapted to

The SEE-NOW-BUY-

NOW Development (Based on case studies and Independent Observers)
As such, from the discourse there was a consensus that the steps that could be merged are: collection viewing with order; work on critical path with price-point planning; delivery to store with order checking and preparation for customers to purchase. Therefore, the process can be shortened to only the production and delivery time by means of an agile supply chain through continuous monitoring, analysing and planning, as well as closer relationships between MBFR and supplier through collaborations and information-sharing, implying a higher flexibility and the use of QR. This differs from the traditional BMSCP that advocates a considerable time spent on range planning and selection of products in the collection viewing which takes place in a showroom six months prior to the launch as opposed to just before it and via a virtual system. Furthermore, traditional BMSCP's require considerable time to be spent on critical path planning and a review of the post-mortem report, analysing best and worst sellers in order to inform the sales forecast and price-point of the upcoming range, all of which is done much hastily under see-now-buy-now making it a higher risk strategy in terms of accurate sales forecasts.

In summary, a framework depicting the BMSCP of MBFRs that incorporates see-nowbuy-now has been developed based on the triangulation of findings from the case studies and external observers (Figure 3).

Adopting see-now-buy-now, merchandisers' tasks of sales and performance analysis are still done at the beginning of the process but are complemented by trend, competitor and market analysis in collaboration with buyers. Hence, see-now-buy-now facilitates a more hybrid role for buying and merchandising, making the traditional roles and responsibilities of buyers and merchandisers much more blurred and overlapping than those discussed by Goworek (2007) and Jackson and Shaw (2001). Budgeting and merchandise planning remain a shared effort between buyers and merchandisers but additionally includes suppliers and is done in parallel to sales and performance review. Hence, the adoption of see-now-buy-now has changed the traditional scope of buying and merchandising roles and requires further integration between the two and a closer relationship with suppliers than ever before. Stock management, delivery and allocation planning are still applicable but are also done in closer collaboration between merchandisers, buyers and suppliers in the time between production and order delivery, not after merchandise arrival at the MBFR's premises. Buyers' task of supplier negotiations is still done but in contrast to the traditional MBSCP, negotiations take place at the buying appointment, whilst pricing decisions are made after the order is placed. It is this process that provides the brand (supplier) with more power than the buyer as the collection is already created by this point and time is pressing as it is about to launch, often causing buyers to over-buy items.

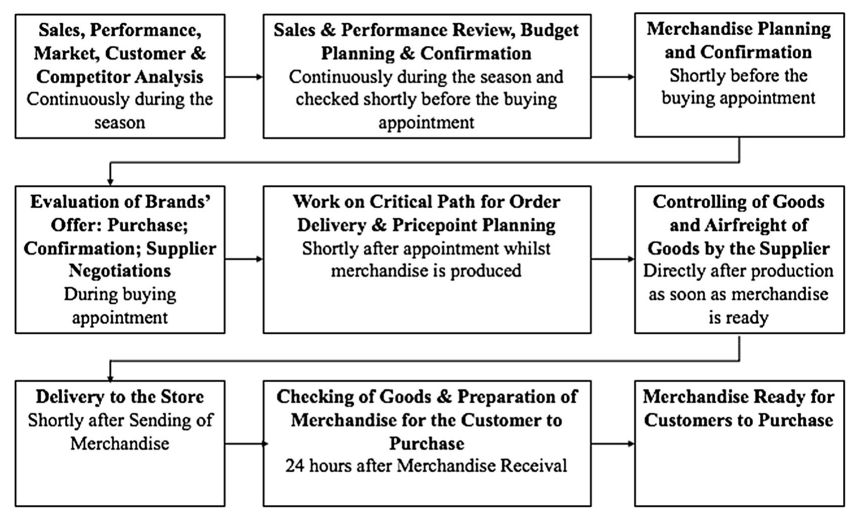


Thus, under see-now-buy-now, buying (Jackson and Shaw, 2001; Goworek, 2007; Kumar and Banga, 2007; Shaw and Koumbis, 2014; Varley, 2014; Varley and Rafiq, 2014; Clark, 2014), merchandising (Jackson and Shaw, 2001; Levy and Weitz, 2004; Kumar and Banga, 2007; Rosenau and Wilson, 2014; Varley, 2014; Shaw and Koumbis, 2014; Clark, 2014) and supply chain (Fisher and Raman, 1996; Jackson and Shaw, 2001; Hoover et al., 2001; Iannone et al., 2013; MacCarthy and Jayarathne, 2013) tasks appear to be unchanged, but are shortened and performed in much closer collaboration between buyers, merchandisers and suppliers, implying much closer internal and external integration and the emergence of hybrid roles.

The main difference between the BMSCP under see-now-buy-now and the traditional BMSCP is the point within the process where end-consumers can see brands' collections. Within the traditional BMSCP customers can see the products in the middle of the process as the brands advertise them pre-season at fashion shows before they can be purchased, whilst with see-now-buy-now consumers can see the merchandise when it arrives in store as brands advertise the collections in-season. Therefore, the novelty of the see-now-buy-now process is not the in-season purchasing by MBFR (Milnes, 2017a) but the increased speed through which merchandise is delivered in-season to cater to customer demand at its peak. BMSCP are made more efficient through agility by means of process alignment and network integration to reduce steps and lead-times which better caters to modern customers' needs for instant gratification and fashion immediacy. Therefore, this study has demonstrated that recurring themes for seenow-buy-now are stronger process and network integration, lead-time shortening, the facilitation of a hybrid buying and merchandising role and closer buyer-merchandiser-supplier relationship management. Consequently, this study adds to existing research on MBFR, buying, merchandising and supply chain by offering a BMSCP not only adapted to MBFR but also adjusted to current customers' needs through the adaption to see-now-buy-now.

\section{Conclusion and implications}

This research demonstrates that the implications of see-now-buy-now on the traditional BMSCP of MBFR are mainly related to agility within the supply chain through flexibility and responsiveness as well as process and network-integration by means of lead-time reduction and supplier-relationship management. Hence, this research found that the application of QR to both internal and external stimuli renders MBFRs' BMSCP more agile. As such, this research shows that agility is necessary within a see-now-buy-now adapted BMSCP through the reduction of all-time spans within each step of the supply chain (Ciarnienéa and Vienažindiené, 2014) through gathering and analysis of PoS data (Mattila et al., 2002; Christopher et al., 2004). This research demonstrates that most steps of the traditional BMSCP are still applicable under see-now-buy-now but have to be re-engineered and shortened. Multiple steps within MBFRs' BMSCP could be combined and executed in parallel. Moreover, MBFRs' BMSCP are found to be rolling processes with continuous analysis and planning connecting multiple internal and external functions. As such, buyers and merchandisers adopt a more hybrid approach to their roles, overlapping their traditional responsibilities with each other, contrasting to previous literature (Jackson and Shaw, 2001; Goworek, 2007; Clark, 2014). Therefore, the BMSCP adapted to see-now-buy-now is suitable for verticallyintegrated retailers with their process and network integration by means of informationsharing and collaboration. Thus, MBFR need to develop towards a vertical-integration through close relationships with suppliers. Consequently, the key findings are the need for a process-shortening, as well as better process and network alignment between MBFR and brands through agility, supplier-relationship management and vertical integration of MBFR to stay competitive against time-based competition and the need for more of a hybrid buying and merchandising role.

This study contributes to knowledge through the exploration of see-now-buy-now and its implications on the traditional BMSCP and the subsequent creation of a new BMSCP 
JFMM

24,3

512

framework. Research on see-now-buy-now from a MBFR's holistic BMSCP viewpoint does not exist, thus this research framework can be used as a basis for future studies on buying and merchandising processes. Contrasting existing research, this study takes a process-view rather than focusing on individual process steps. Therefore, this study contributes to knowledge through the establishment of a holistic BMSCP adapted to MBFR through the consolidation of multiple own-label buying BMSCP models and application of those to MBFR.

Prior studies have described the BMSCP as consecutive and lengthy (Johnston and Lewin, 1996; Johansson, 2001; Kök et al., 2006; Goworek, 2007; Kumar and Banga, 2007; Iannone et al., 2013; Varley and Rafiq, 2014; Clark, 2014; Shaw and Koumbis, 2014), which suggests that the traditional BMSCP processes do not cater to the current fashion consumers' needs. However, this study provides a new framework whereby multiple steps can be combined and executed in parallel, which may shorten the process from 12 months to 3 months. As such, the findings can be used to assist practitioners in buying, merchandising, supply chain, general management and consulting in streamlining business processes towards network integration, with a revised business strategy, which is necessary to stay competitive in today's consumer-driven fashion market.

\section{Limitations and future research}

Given the difficulties in gaining access to industry participants, one or two interviews per case study were conducted which is considered a limitation. Whilst this delivered sufficient information, as data saturation was reached, additional interviews will increase validity and complement theoretical replication with literal replication (Yin, 2014). Moreover, the findings are limited to German and UK MBFRs. Hence, future research on see-now-buy-now's impact on global brands and their subsequent process adaption from either a process point-of-view or a focus on specific steps would be beneficial, expanding research to different geographies. Furthermore, as the brands adopting see-now-buy-now to date are primarily high-end or luxury, the focus of this research was on this market, thus future research could investigate whether there are any differences for fast-fashion retailers. Further, as the fashion industry is subject to rapid change, it would be interesting to investigate iterative business models that enable speed-to-market and newness, like "product drops" within and across market levels, from both a retailer and consumer perspective.

\section{References}

ATKearney (2018), "See now, buy now-closing the gap between runway and retail", available at: https://www.atkearney.de/documents/856314/10972252/ATKInsights_SeeNowBuyNow.pdf/ 9cb0433a-8e03-49e5-b51b-0705ceece09d (accessed 30 July 2019).

Berg, A., Heyn, M., Rölkens, F. and Simon, P. (2018), "Faster fashion: how to shorten the apparel calendar", available at: https://www.mckinsey.com/industries/retail/our-insights/faster-fashionhow-to- shorten-the-apparel-calendar (accessed 30 July 2018).

Berman, B. and Evans, J.R. (2013), Retail Management: A Strategic Approach, 12th ed., Pearson, Harlow.

Blessley, M., Mir, S., Zacharia, Z. and Aloysius, J. (2018), "Breaching relational obligations in a buyersupplier relationship: feelings of violation, fairness perceptions and supplier switching", Industrial Marketing Management, Vol. 74, October, pp. 215-226.

Boardman, R., Parker-Strak, R. and Henninger, C.E. (2020), Fashion Buying and Merchandising: The Fashion Buyer in a Digital Society, Routledge, London.

Brandes, H. (1994), "Strategic changes in purchasing: two main tracks", European Journal of Purchasing \& Supply Management, Vol. 1 No. 2, pp. 77-87. 
Brown, H. (2016), "What London fashion week says about 'see now, buy now' and brexit", Drapers, available at: https://www.drapersonline.com/product-and-trade-shows/catwalks/london-fashionweek/what-london-fashion-week-says-about-see-now-buy-now-and-brexit/7012198.article (accessed 26 August 2018).

Bruce, M. and Daly, L. (2006), "Buyer behaviour for fast fashion”, Journal of Fashion Marketing and Management: International Journal, Vol. 10 No. 3, pp. 329-344.

Christopher, M., Lowson, R. and Peck, H. (2004), "Creating agile supply chains in the fashion industry”, International Journal of Retail \& Distribution Management, Vol. 32 No. 8, pp. 367-376.

Clark, D. (2014), Fashion Merchandising - Principles and Practice, Palgrave Macmillan, Basingstoke.

Cooper, B., (2017), "Analysis: the rise of the multi-brand store", Retail Week, available at: https://www. retail-week.com/analysis-the-rise-of-the-multi-brand-store/7020274.article?authent =1 (accessed 27 August 2019).

Coresight Research (2018), "From runway to checkout: the see- now-buy-now trend in fashion", available at: https://www.fungglobalretailtech.com/research/runway-checkout-see-now-buynow- trend-fashion/ (accessed 30 July 2018).

Eisenhardt, K.M. and Graebner, M.E. (2007), "Theory building from cases: opportunities and challenges", Academy of Management Journal, Vol. 50 No. 1, pp. 25-32.

Fernie, J. and Grant, D.B. (2015), Fashion Logistics: Insight into the Fashion Retail Supply Chain, KoganPage, London.

Fernie, J. and Sparks, L. (2014), Logistics and Retail Management: Emerging Issues and New Challenges in the Retail Supply Chain, KoganPage, London.

Fisher, M. and Raman, A. (1996), "Reducing the cost of demand uncertainty through accurate Response to early sales", Journal of Operations Research, Vol. 44 No. 1, pp. 87-99.

Gabriel, Y. and Griffiths, D.S. (2004), "Stories in organizational research", in Cassell, C. and Symon, G. (Eds), Essential Guide to Qualitative Methods in Organizational Research, SAGE, London, pp. 114-126.

Goworek, H. (2007), Fashion Buying, Blackwell Publishing, Oxford.

Goworek, H. (2010), “An investigation into product development processes for UK fashion retailers: a multiple case study", Journal of Fashion Marketing and Management: International Journal, Vol. 14 No. 4, pp. 648-662.

Grohmann, B., Spangenberg, E.R. and Sprott, D.E. (2007), "The influence of tactile input on the evaluation of retail product offerings", Journal of Retailing, Vol. 83 No. 2, pp. 237-245.

Grose, V. (2012), Fashion Merchandising, Bloomsbury, New York, NY.

Hagenmüller, M. and Wolff, R. (2017), "Your multi-brand apparel strategy", available at: https://www. accenture.com/us-en/insight-tailoring- your-multi-brand-apparel-strategy (accessed 27 August 2018).

Hargrave, S. (2015), “Can independent retailers survive on UK high streets?”, Telegraph available at: https://www.telegraph.co.uk/sponsored/business/the-elevator/12053724/advice-for-independentretailers.html (accessed 20 June 2019).

Hines, T. and McGowan, P. (2002), "Retail sourcing and procurement strategies in the UK fashion industry - an exploratory study of contemporary supply relationships", Textile Institute, Vol. 93 No. 3, pp. 80-94.

Hoegl, M. and Wagner, S.M. (2005), "Buyer-supplier collaboration in product development projects", Journal of Management, Vol. 31 No. 4, pp. 530-548.

Hoover, W., Eloranta, E., Holmström, J. and Huttunen, K. (2001), Managing the Demand-Supply Chain, Wiley, New York, NY.

Iannone, R., Ingenito, A., Martino, G., Miranda, S., Pepe, C. and Riemma, S. (2013), "Merchandise and replenishment planning optimisation for fashion retail", International Journal of Engineering Business Management - Special Issue on Innovations in Fashion Industry, Vol. 5, pp. 1-14. 
JFMM 24,3

514

Jackson, T. and Shaw, D. (2001), Mastering Fashion Buying and Merchandising Management, Palgrave Macmillan, Basingstoke.

Jacobs, D. (2006), "The promise of demand chain management in fashion", Journal of Fashion Marketing and Management: International Journal, Vol. 10 No. 1, pp. 84-96.

Jamshed, S. (2014), "Qualitative research method-interviewing and observation”, Journal of Basic and Clinical Pharmacy, Vol. 5 No. 4, p. 87.

Johansson, U. (2001), "Retail buying: process, information and IT use: a conceptual framework", International Review of Retail Distribution \& Consumer Research, Vol. 11 No. 4, pp. 329-357.

Johnston, W.J. and Lewin, J.E. (1996), "Organizational buying behavior: toward an integrative framework", Journal of Business Research, Vol. 35 No. 1, pp. 1-15.

Kim, Y. and Choi, T.Y. (2015), "Deep, sticky, transient, and gracious: an expanded buyer-supplier relationship typology", Journal of Supply Chain Management, Vol. 51 No. 3, pp. 61-86.

Kök, A.G., Fisher, M.L. and Vaidyanathan, R. (2006), "Assortment planning: review of literature and industry practice", International Series in Operations Research \& Management Science Book Series, Vol. 122, pp. 99-153.

Kumar, B. and Banga, G. (2007), "Merchandise planning: an indispensable component of retailing", The Icfaian Journal of Management Research, Vol. 6 No. 11, pp. 7-19.

Kvale, S. (2007), Doing Interviews, Sage, Thousand Oaks, CA.

Kunz, G.I. and Rupe, D. (1999), "Volume per stock-keeping unit for an assortment: a merchandise planning tool”, Journal of Fashion Marketing and Management: International Journal, Vol. 3 No. 2, pp. 118-125.

Levy, M. and Weitz, B.A. (2004), Retailing Management, McGraw-Hill/Irwin, New York, NY.

Lockwood, L. and Edelson, S., (2016), "Instant fashion-salvation or gimmick?”, Women's Wear Daily, available at: https://wwd.com/fashion-news/designer-luxury/instant-fashion-salvation-gimmick10673655/ (accessed 30 July 2019).

MacCarthy, B.L. and Jayarathne, P.G.S.A. (2013), "Supply network structures in the international clothing industry: differences across retailer types", International Journal of Operations \& Production Management, Vol. 33 No. 7, pp. 858-886.

Macchion, L., Dansese, P. and Vinelli, A. (2015), "Redefining supply network strategies to face changing environments. A study from the fashion and luxury industry", Journal of Operations Management Research, Vol. 8 Nos 1-2, pp. 15-31.

Mattila, H., King, R. and Ojala, N. (2002), "Retail performance measures for seasonal fashion”, Journal of Fashion Marketing and Management, Vol. 6 No. 4, pp. 340-351.

Mehrjoo, M. and Pasek, ZJ. (2014), "Risk assessment for the supply chain of fast fashion apparel industry: a system dynamics framework", International Journal of Production Research, Vol. 54 No. 1, pp. 28-48.

Milnes, H. (2017a), The see-now-buy-now revolution is fizzling", Glossy, available at: https:/www.glossy. co/fashion-calendar/see-now-buy-now-has-officially-hit-a-wall?utm_source=digiday.com\&utm_m edium $=$ referral\&utm_campaign $=$ digidaydis\&utm_content $=($ accessed 28 August 2019).

Milnes, H. (2017b), "Three seasons in, see-now-buy-now is going nowhere", Digital UK, available at: https://digiday.com/marketing/three-seasons-see-now-buy-now-going-nowhere/ (accessed 28 August 2019).

Milnes, M.B., Huberman, A.M. and Saldana, J. (2014), Qualitative Data Analysis: A Methods Sourcebook, SAGE, Los Angeles, CA.

Mountney, H. and Murphy, D. (2017), "See now buy now how ready are you?", available at: https:// www.accenture.com/t20170531T020308Zw/us-en/acnmedia/PDF- 53/Accenture-Strategy-DDSee-Now-Buy-Now.pdf (accessed 30 July 2018). 
Müller, J.M., Buliga, O. and Voigt, K. (2018), "Fortune favors the prepared: how SMEs approach business model innovations in Industry 4.0", Journal of Technological Forecasting and Social Change, Vol. 132, July, pp. 2-17.

Narayanan, S., Narasimhan, R. and Schoenherr, T. (2015), "Assessing the contingent effects of collaboration on agility performance in buyer-supplier relationships", Journal of Operations Management, Vol. 33-34, January 2015, pp. 140-154.

Oppenheim, A.N. (1992), Questionnaire Design, Interviewing and Attitude Measurement, Continuum, London.

Panchmatia, M. (2017), "See now, buy now" sourcing and the fashion industry", available at: https:// www.4cassociates.com/see-now-buy-now-sourcing-fashion-industry/ (accessed 26 August 2018).

Patton, M.Q. (2015), Qualitative Research and Evaluation Methods, SAGE, California.

Peck, J. and Childers, T.L. (2003), "To have and to hold: the influence of haptic information on product judgments", Journal of Marketing, Vol. 67 No. 2, pp. 35-48.

Perry, P. and Kyriakaki, M. (2014), "The decision-making process of luxury fashion retail buyers in Greece", Journal of Fashion Marketing and Management, Vol. 18 No. 1, pp. 85-106.

Reichhart, A. and Holweg, M.. (2007), "Creating the customer-responsive supply chain: a reconciliation of concepts", International Journal of Operations \& Production Management, Vol. 27 No. 11, pp. 1144-1172.

Rosenau, J.A. and Wilson, D.L. (2014), Apparel Merchandising: The Line Starts Here, Fairchild Books, New York.

Saunders, M., Lewis, P. and Thornhill, A. (2012), Research Methods for Business Students, Pearson Education, Harlow.

Schwandt, T.A. (2001), Dictionary of Qualitative Inquiry, SAGE Publications, Thousand Oaks, CA.

Shaw, D. and Koumbis, D. (2014), Fashion Buying: From Trend Forecasting to Shop Floor, Fairchild Books, London.

Sherman, L. (2017), "The state of fashion immediacy”, The Business of Fashion, available at: https://www. businessoffashion.com/articles/intelligence/the-state-of-fashion-immediacy (accessed 30 July 2018).

Sheth, J. (1981), "A theory of merchandise buyer behaviour", Faculty working papers, College of Commerce and Business Administration. Urbana Champaign, University of Illinois, Chicago, IL.

Swanborn, P. (2010), Case Study Research: what, Why and How?, SAGE Publications, London.

Swoboda, B., Pop, N. and Dabija, D.C. (2010), "Vertical alliances between retail and manufacturer companies in the fashion industry", Amfiteatru Economic Journal, Vol. 12 No. 28, pp. 634-649.

Varley, R. (2014), Retail Product Management - Buying and Merchandising, Routledge, Abingdon.

Varley, R. and Rafiq, M. (2014), Principles of Retailing, Palgrave Macmillan, Basingstoke.

Webster, F.E. and Wind, Y. (1972), "A general model for understanding organizational buying behavior", Journal of Marketing, Vol. 36 No. 2, pp. 12-19.

Woodworth, S. (2018), "How high-end multibrand stores dominate online luxury retail", available at: https://luxe.digital/digital-luxury-reports/high-end- multibrand-stores-dominate-online-luxuryretail/ (accessed 28 August 2018).

Yin, R.K. (2014), Case Study Research: Design and Methods, SAGE Publications, California.

\section{Corresponding author}

Rosy Boardman can be contacted at: rosy.boardman@manchester.ac.uk

For instructions on how to order reprints of this article, please visit our website:

www.emeraldgrouppublishing.com/licensing/reprints.htm

Or contact us for further details: permissions@emeraldinsight.com 